\title{
MASLAHAT MEMELIHARA HARTA DALAM SISTEM EKONOMI ISLAM ${ }^{*}$
}

\author{
Andi Iswandi ${ }^{1}$ \\ Permalink: https://www.academia.edu/9964013
}

\begin{abstract}
The Benefits of Maintaining Property in Islamic Economic System. property in the Islamic economic system has an important position. Related in business activities of economic and ritual worship, in Sharia maqoshid, preserve or maintain the property is one of important point. It is the intent and purpose of God in order to give the benefit of the people to pray to serve as guidelines in the business and dealing with. The benefit in preserving and maintaining the property is an economic system that has been set by Allah swt. Economic system does not belong by any religion other than Islam. This system provides guidance on how humans earn their living, consuming materials, conduct transactions, distribute assets, and conduct religious activities like charity, donation and alms.
\end{abstract}

Keywords: Benefits, Maintaining Property, Sharia Maqoshid, Islamic Economic System

\begin{abstract}
Abstrak: Maslahat Memelihara Harta Dalam Sistem Ekonomi Islam. Harta di dalam sistem ekonomi Islam memiliki kedudukan yang penting. Dalam kaitannya dengan kegiatan bisnis ekonomi dan ritual ibadah, harta diperhatikan betul, sehingga di dalam maqoshid syariah menjadikannya salah satu point penting yaitu, memelihara atau menjaga harta. Hal ini adalah maksud dan tujuan Tuhan dalam rangka memberikan kemaslahatan kepada manusia untuk kiranya dijadikan sebagai pedoman di dalam berbisnis dan bermuamalah. Kemaslahatan di dalam memelihara ataupun menjaga harta merupakan sistem ekonomi yang diberikan Allah Swt., yaitu sistem ekonomi yang tidak dimiliki oleh agama lain selain agama Islam. Sistem inilah yang memberikan pedoman bagaimana manusia mencari nafkah, mengkonsumsi materi, melakukan transaksi jualbeli, mendistribusikan harta, dan melakukan kegiatan ibadah seperti zakat, infak dan sedekah.
\end{abstract}

Kata Kunci: maslahat, memelihara harta, maqoshid syariah, sistem ekonomi Islam

Diterima tanggal naskah diterima: 02 Maret 2014, direvisi: 25 April 2014, disetujui untuk terbit: 10 Juni 2014.

${ }^{1}$ Fakultas Syariah, Perguruan Tinggi Ilmu al-Quran (PTIQ), Jakarta. Jl. Batan 1 No. 2 Lebak Bulus Cilandak Jakarta Selatan. Email: swan_saputra@yahoo.com 


\section{Pendahuluan}

Sejatinya, kajian yang membahas harta dan sistem ekonomi Islam saat ini adalah perihal yang sangat penting, mengingat pertumbuhan dan perkembangan ekonomi Islam yang membutuhkan akan konsep dan sistem dari ekonomi Islam tersebut mendapatkan respon yang sangat luar biasa dari masyarakat umumnya, dan khususnya dari kalangan akademisi ataupun praktisi. Hal ini sejalan dengan pesatnya pertumbuhan industri syariah, lembaga keuangan dan perbankan syariah. Begitu pula dengan banyaknya program studi ekonomi syariah yang telah dibuka di berbagai kampus.

Menurut pandangan beberapa tokoh ekonomi Islam, seperti Wahbah al-Zuhaili, pembahasan akan harta dan ekonomi Islam haruslah di bawah naungan syariah Islamiyah, yang tidak terlepas dari maqoshid syariah dimana di dalamnya terdapat kemaslahatan yang diberikan Allah swt kepada manusia demi kebaikan hidup di dunia ataupun di akhirat. ${ }^{2}$ Pandangan ini menyiratkan bahwa, Islam dengan perangkat syariahnya mengatur harta dan bagaimana pemeliharaan harta yang diinginkan oleh al-Syaari (Sang Pembuat Hukum; Allah swt).

\section{Maslahat Menurut Ulama Ushul Fiqh}

Menelusuri makna maslahat tidak terlepas dari pemaknaan yang mutlak dan pemaknaan yang bersifat majazi. Makna mutlak maslahat disini adalah suatu nilai manfaat yang dihasilkan, yaitu kesempurnaan manfaat dari target yang diinginkan. Sedangkan makna majazi adalah suatu faktor yang menyebabkan terjadinya nilai manfaat, atau dimaknai sebagai suatu usaha yang terkandung di dalamnya nilai-nilai manfaat sebagai permisalan adalah usaha atau kegiatan bisnis dan pertanian adalah usaha yang terkandung di dalamnya nilai-nilai maslahat karena usaha tersebut memang memberikan manfaat atau faktor yang memberikan nilai maslahat itu sendiri. ${ }^{3}$ Pemaknaan ini merumuskan bahwa maslahat adalah manfaat itu sendiri, terlepas nilai manfaat itu sebagai out put atau nilai manfaat itu sebagai process.

Untuk memahami lebih jauh tentang maslahat sebagai out put ataupun process, berikut pemaknaan maslahat menurut ulama ushul fiqh:

Pertama, Al-Ghazali. Sebagai pelopor ulama syafi'iyah, dalam kitabnya yang berjudul al-Mustashfa, al-Ghazali memaknai maslahat sebagai usaha didalam mengambil nilai-nilai manfaat dan menafikan nilai-nilai kerusakan. Dimana usaha ini (process) ditujukan untuk menjaga tujuan syariat (maqoshid al-syariah), yaitu: menjaga agama (حفظ الدين), menjaga jiwa (حفظ النفس), menjaga akal (حفظ العقل), menjaga keturunan (حفظ النسل), dan menjaga harta (حفظ المال). Dari pemaknaan maslahat disini al-Ghazali berpendapat bahwa segala usaha

${ }^{2}$ Lihat, Wahbah al-Zuhaili, Maqhosid al-Syariah al-Islamiyah fi al-Mal wa al-Iqtishad al-Islami, makalah disampaikan dalam seminar The Second Islamic Economics and Finance Research Forum oleh Ikatan Ahli Ekonomi Islam di UIN Syarif Hidayatullah Jakarta 13-14 November 2013. h. 4.

${ }^{3}$ Lihat, Dr. Musthofa zaid, al-Maslahah fi al-Tasyri al-Islami, (Mesir: Matba'ah alJaizah), h. 18-19. 
yang ditujukan untuk menjaga tujuan syariat (maqoshid al-syariah) adalah maslahat atau nilai-nilai manfaat, sedangkan segala usaha yang menafikan tujuan syariat (maqoshid al-syariah) adalah mafsadat atau nilai-nilai kerusakan. ${ }^{4}$

Kedua, Al-Khowarizimi. Salah satu ulama ushul fiqh hanafiyah ini memaknai maslahat sebagai usaha menjaga tujuan syariat (maqoshid al-syariah) dengan menafikan mafsadat atau nilai-nilai kerusakan yang ditimbulkan oleh perilaku manusia. ${ }^{5}$ Makna maslahat yang diketengahkan al-Khowarizimi sebenarnya tidak jauh berbeda dengan al-Ghazali, akan tetapi makna maslahat yang diketengahkan al-Khowarizimi lebih bersifat umum.

Ketiga, Al-Thufi. Menurutnya maslahat dimaknai sebagai wazn dari kata mafalatun dari kata sholaha, yang berarti bentuk suatu materi dibuat sedemikian rupa sesuai dengan kegunaannya. Semisal, pena dibuat sedemikian rupa agar dapat digunakan untuk menulis, dan pedang dibikin sedemikian rupa sehingga bisa dipakai untuk memenggal. Sedangkan makna maslahat yang diungkapnya adalah sarana yang menyebabkan adanya maslahat dan manfaat. Misalnya, perdagangan adalah sarana untuk mencapai keuntungan. Pengertian berdasarkan syariat adalah sesuatu yang menjadi penyebab untuk sampai kepada tujuan syariat (maqoshid al-syariah), baik berupa ibadat maupun adat. Kemudian, maslahat ini terbagi menjadi dua bagian, yaitu perbuatan yang memang merupakan tujuan syariat (maqoshid al-syariah), yakni ibadat dan apa yang dimaksudkan untuk kemanfaatan semua umat manusia dan tatanan kehidupan, seperti adat istiadat. ${ }^{6}$ Makna maslahat yang diungkap al-Thufi tampak lebih rinci, karena maslahat yang dijelaskannya juga digambarkan dengan permisalan dari kegiatan ibadat dan adat. Dalam hal adat, al-Thufi lebih jauh memberikan permisalan yang umum kita kenal di dalam kegiatan muamalah dan bisnis, dinyatakan bahwa process dari kegiatan bisnis perdagangan adalah sebagai sarana untuk mendapatkan maslahat dan nilai-nilai manfaat yang dibutuhkan pelaku bisnis, yaitu keuntungan. Dengan penjelasan ibadat dan adat, sebenarnya al-Thufi mencoba menjelaskan tentang hak Allah swt sebagai Tuhan dan hak manusia sebagai khalifah di muka bumi ini.

Keempat, Ibnu Abdi Salam. Salah satu ulama syaf'iah ini memaknai maslahat dalam jumlah pemaknaan yang beragam, dalam karya monumentalnya Qowaid al-Ahkam fi Masholihu al-Anam dijelaskan bahwa maslahat terbagi menjadi empat jenis, yaitu hakiki yang terdiri dari kesenangan dan kelezatan, dan majazi yang terdiri dari faktor dari kesenangan dan faktor dari kelezatan. Begitu juga dengan mafsadat yang juga terbagi menjadi empat jenis, yaitu hakiki yang terdiri dari rasa sakit dan rasa gelisah, dan majazi yang

${ }^{4}$ Lihat, al-Ghazali, al-Mustashfa min Ilmi al-Ushul, (Beirut: Darul Ulum al-Haditsah), h. 286 .

${ }^{5}$ Lihat, al-Syaukani, Irsyadul fuhul ila Tahqiqi al-Haq min Ilmi al-Ushul, (Mesir: Matba'ah al-Babi al-Halabi), h. 242.

${ }^{6}$ Lihat, al-Thufi, al-Maslahah fi al-Tasyri al-Islami, h. 19. Dan Dr. Muhammad Ahmad al-Mabid, Maslahah Hifdzu al-Nafsi fi al-Syariah al-Islamiyah, (Mesir: Muasasah alMukhtar, 2004), h. 28. 
terdiri dari faktor dari rasa sakit dan rasa gelisah. ${ }^{7}$ Ibnu Abdi Salam mengungkapkan bahwa terkadang suatu mudharat dapat menghasilkan kemaslahatan, sehingga mudharat tersebut diperbolehkan atau diperintahkan untuk mengerjakannya. Akan tetapi kebolehan dan perintah tersebut bukan karena kemadharotannya secara esensial, melainkan karena dipandang mudharat tersebut menjadi penyebab dari adanya kemaslahatan tertentu. Semisal, mengamputasi organ tubuh yang dapat menularkan penyakit kesuluruh tubuh sebagai bentuk penjagaan jiwa (حفظ النفس) terhadap keberlangsungan hidup, mempertaruhkan nyawa dalam berjihad, begitu juga seluruh bentuk hukuman-hukuman yang diterapkan dalam syariat, kesemuanya itu diperintahkan bukan karena kemudharatannya, akan tetapi lebih dipandang pada kemaslahatan yang terkandung dibalik semua itu, hukuman potong tangan bagi pencuri, atau perampok, hukuman qishos, rajam, cambuk, atau pengisolasian (taghrib) bagi orang yang berzina, hukuman yang berupa ta'zir, keseluruhannya termasuk mudharat yang diperintahkan oleh syariat, demi untuk merealisasikan kemaslahatan.

Kelima, Al-Syathibi. Menyatakan bahwa yang dimaksud dengan maslahat dalam pengertian istilah syar'i adalah mengambil manfaat dan menolak mafsadat yang tidak hanya berdasarkan kepada akal sehat semata, tapi dalam rangka memelihara hak hamba. Al-Syathibi lebih lanjut menyatakan bahwa tidak semua kemaslahatan duniawi dapat diketahui oleh akal, namun hanya sebagian, dan lainnya diketahui melalui syariat. Jika akal dapat mengetahui segala kemaslahatan duniawi secara mutlak, syariat hanya berfungsi sebagai pedoman ukhrawi, padahal syariat bermaksud menegakkan keduanya, kehidupan duniawi dan ukhrawi. ${ }^{8}$ Dari beberapa pemaknaan maslahat diatas dapat ditarik kesimpulan bahwa maslahat adalah upaya mengambil nilai-nilai manfaat dan menafikan nilai-nilai kerusakan, dimana keduanya (manfaat dan kerusakan) dapat dijadikan sebagai wasilah di dalam menegakan tujuan syariat (maqoshid al-syariah) untuk kepentingan kehidupan manusia di dunia dan akhirat.

\section{Formula Tingkat Kemaslahatan}

Kemaslahatan syariah islamiyah di dalam menegakan tujuan syariat (maqoshid al-syariah) terdiri dari tingkatan yang berbeda dan tidak berada pada satu kesatuan tingkat, yaitu: pertama, dhoruriyat adalah perihal utama dan penting, semisal dalam menjaga harta (حفظ المال) bahwa Islam menjadikan hal utama dan penting pada perihal wajib mencari nafkah dan perihal kehalalan atasnya; kedua, hajiyat adalah perihal yang diperlukan untuk mendukung perihal utama yaitu dhoruriyat, semisal akad atau kontrak di dalam kegiatan bisnis untuk mendukung perihal utama di dalam mencari nafkah adalah sesuatu yang diperlukan (hajiyat) keberadaannya; ketiga, tahsiniyat adalah perihal yang

\footnotetext{
${ }^{7}$ Ibnu Abdi Salam, Qowaid al-Ahkam fi Masholihu al-Anam, (Beirut: Darul Jail), jilid 1, h. 11

${ }^{8}$ Al-Syathibi, al-Muwafaqot fi Ushul al-Syariah, (Kairo: Musthofa Muhammad), jilid 2, h. 374 .
} 
menyempurnakan untuk tingkatan pertama dan kedua, semisal untuk mendukung perihal utama di dalam mencari nafkah dan perihal kedua di dalam akad dan transaksi bisnis maka perihal yang menyempurnakan untuk kedua tingkatan diatas adalah etika dan prilaku bisnis yang baik.

Para ulama ushul fiqh sepakat, bahwa peringkat kemaslahtan diatas haruslah tertib, yaitu tingkat pertama haruslah ditempati dhoruriyat, tingkat kedua adalah hajiyat dan tidak diperkenankan untuk menempati tingkat pertama, dan ketiga adalah tahsiniyat dan tidak diperkenankan untuk menempati tingkat kedua apalagi tingkat pertama. Hal ini dimaksudkan agar menegakan tujuan syariat (maqoshid al-syariah) yang terdiri dari menjaga agama (حفظ الدين), menjaga jiwa (حفظ النفس), menjaga akal (حفظ العقل), menjaga keturunan (حفظ النسل), dan menjaga harta (حفظ المال) untuk kepentingan kehidupan manusia di dunia dan akhirat sesuai dan tidak terjadi tumpangtindih. $^{\text {. }}$

Sejatinya, tingkat kemaslahatan di dalam menegakan tujuan syariat (maqoshid al-syariah) adalah formula yang sangat penting untuk dikaji, karena dengan tingkat kemaslahatan ini kita dapat mengetahui bahwa perihal yang penting (dhoruriyat) adalah penting adanya dan tidak bisa diturunkan peringkatnya menjadi perihal yang dibutuhkan/diperlukan (hajiyat) apalagi menjadi perihal yang menyempurnakan (tahsiniyat). Hal ini juga berlaku di dalam sistem ekonomi dimana perihal yang primer harus diutamakan dari perihal yang sekunder dan perihal yang tersier. Semisal, untuk menjaga keberlangsungan hidup adalah perihal primer yang harus diutamakan, dan untuk mendukung keberlangsungan hidup dibutuhkan mengkonsumsi makanan yang menjadi hal yang sekunder, dan tentunya untuk menyempurnakan keberlangsungan hidup dan makanan yang dibutuhkan, maka kebutuhan hal yang tersier menjadi tahapan selanjutnya.

\section{Harta Dalam Sistem Ekonomi Islam}

Harta dalam bahasa Arab adalah (الهـال) yang berarti condong, cenderung dan miring, dalam hal ini adalah kecenderungan manusia untuk memiliki dan menguasai materi harta. Dan harta yang dimaksud disini adalah segala sesuatu yang dibutuhkan dan diperoleh manusia, baik berupa benda yang tampak seperti emas, perak, binatang, tumbuh-tumbuhan, maupun yang tidak tampak, yakni manfaat semisal yang berada pada kendaraan, pakaian, dan tempat tinggal. Dan sesuatu yang tidak dikuasai manusia tidak bisa dikatakan harta menurut bahasa, seperti burung di udara, ikan di lautan lepas, pohon di hutan, dan barang tambang yang di bumi. ${ }^{11}$

\footnotetext{
${ }^{9}$ Lihat, Yusuf al-Qordhowi, Fi Fiqh al-Awlawiyat, (Beirut: al-Maktab al-Islami, 1999), h. 25-28.

${ }^{10}$ Lihat, Wahbah al-Zuhaili, Nadhoriyat al-Dhoruroh al-Syariyah, (Beirut: Darul Fikri al-Muasir, 1997), h. 44-55.

${ }^{11}$ Wahbah al-Zuhaili, al-Figh al-Islami wa Adilatuhu, (Damaskus: Darul Fikri, 1989), jilid 4, h. 40 .
} 
Sedangkan definisi harta secara istilah terbagi menjadi dua pendapat ulama fiqih, yaitu:

Pertama, Pendapat Ulama Hanafiyah. Harta adalah segala sesuatu yang dapat diambil, disimpan, dan dapat dimanfaatkan. Menurutnya harta memiliki dua unsur; Pertama, harta dapat dikuasai dan dipelihara. Kedua, dapat dimanfaatkan menurut kebiasaan. Menurut Ibnu Abidin, harta adalah sesuatu yang dapat disimpan dan dapat dipergunakan pada saat yang dibutuhkan. ${ }^{12}$

Kedua, Pendapat Jumhur. Menurut mereka harta adalah segala sesuatu yang bernilai dan mesti rusaknya dengan menguasainya. Atau segala sesuatu yang bernilai dan bersifat harta. Menurut al-Syathibi, harta adalah materi yang dapat dikuasai dan memberikan nilai manfaat. ${ }^{13}$ Dan Imam Syafi'i menjelaskan, bahwa harta adalah materi yang berharga dan dapat dijadikan sebagai alat tukar di dalam kegiatan jual-beli.

Dari definisi harta diatas, ada beberapa perbedaan yang dikemukakan oleh Ulama Hanafiyah dan Jumhur, yaitu tentang benda yang tidak berwujud akan tetapi memberikan nilai manfaat. Ulama Hanafiyah berpendapat bahwa manfaat sesuatu yang dapat dimiliki akan tetapi tidak bisa dikatakan sebagai harta. Sedangkan jumhur berpendapat, manfaat adalah termasuk dari harta sebab yang terpenting adalah manfaatnya dan bukan wujud materinya. ${ }^{15}$ Manfaat yang dimaksudkan disini adalah kegunaan yang dihasilkan dari materi, seperti rumah memberikan kegunaan kepada pemiliknya untuk ditempati.

Adapun hak yang ditetapkan oleh syariah kepada seseorang yang menguasai harta terkadang dikaitkan oleh harta, seperti hak milik, hak untuk meminum, makan dan seterusnya. Akan tetapi, terkadang tidak dikaitkan dengan harta, seperti hak asuh. Ulama Hanafiyah berpendapat bahwa hak yang dikaitkan dengan harta tidak dapat dikatakan sebagai harta, karena tidak dapat dikuasai dan disimpan materi zatnya, meskipun hak milik dapat didapatkan namun seiring waktu akan hilang sedikit demi sedikit, hal itu disebabkan karena sifatnya yang abstrak tidak berwujud. Sedangkan Jumhur berpendapat, bahwa hak milik dan manfaat dapat dipandang sebagai harta sebab dapat dikuasai dengan cara menguasai pokoknya, dan karena maksud dari harta itu adalah manfaat dan kegunaannya.

Dalam sistem ekonomi Islam, harta adalah materi yang kepemilikan mutlaknya berada ditangan Allah swt dan pengelolaannya berada ditangan manusia, Allah swt berfirman: "Dan Kepunyaan Allah-lah kerajaan antara keduanya. Dan kepada Allah-lah kembali." (Q.s. al-Maidah [5]: 18), "Kepunyaan-Nya-lah semua yang ada di langit, semua yang di bumi, semua yang di antara keduanya dan semua yang di bawah tanah.” (Q.s. Toha [20]: 6) dan "Berimanlah kamu kepada Allah dan Rasul-Nya dan nafkahkanlah sebagian

${ }^{12}$ Ibnu Abidin, Hasyiatu Rodu al-Mukhtar, jilid 4, h. 534. Dan Izudin Bin Rogibah, al-Maqoshid al-Syariyah al-Hosoh bi al-Tasyarufat al-Maliyah, h. 28.

${ }^{13}$ Al-Syathibi, al-Muwafaqot fi Ushul al-Syariah, (Kairo: Musthofa Muhammad), jilid 2, h. 332 . 1, h. 184 .

${ }^{14}$ Ibnu Abdi Salam, Qowaid al-Ahkam fi Masholihu al-Anam, (Beirut: Darul Jail), jilid

${ }^{15}$ Rachmat Syafei, Fiqih Muamalah, (Bandung: Pustaka Setia, 2006), h. 23. 
dari hartamu yang Allah telah menjadikan kamu menguasainya. Maka orangorang yang beriman di antara kamu dan menafkahkan (sebagian) dari hartanya memperoleh pahala yang besar." (Q.s. al-Hadid [57]: 7).

Kedudukan manusia sebagai khalifah Allah dalam harta, pada hakikatnya menunjukan bahwa manusia merupakan wakil atau petugas yang bekerja kepada Allah swt. Oleh karena itu, menjadi kewajiban manusia sebagai khalifah Allah untuk merasa terikat dengan perintah-perintah dan ajaran-ajaran Allah tentang harta. Inilah landasan syariat yang mengatur harta, hak dan kepemilikan. Kesemuanya harus sesuai dengan aturan yang memiliki harta tersebut, yaitu aturan Allah swt. ${ }^{16}$

Kalau manusia yang dipercaya untuk menjadi khalifah atas pengelolaan harta tidak lagi menepati perintah Allah dan menjauhi laranganNya, maka Allah swt memiliki kuasa untuk dapat menggantinya dengan orang lain, Allah swt berfirman: "Ingatlah, kamu ini orang-orang yang diajak untuk menafkahkan (hartamu) pada jalan Allah. Maka di antara kamu ada yang kikir, dan siapa yang kikir sesungguhnya dia hanyalah kikir terhadap dirinya sendiri. Dan Allah-lah yang Maha Kaya sedangkan kamulah orang-orang yang berkehendak (kepada-Nya); dan jika kamu berpaling niscaya Dia akan mengganti (kamu) dengan kaum yang lain; dan mereka tidak akan seperti kamu ini." (Q.s. Muhammad [47]: 38).

Dalam sistem ekonomi Islam, harta juga dijadikan wasilah untuk mendukung kegiatan ibadah ataupun muamalah, dalam hal ini Allah swt menjadikan harta sebagai wasilah untuk mendukung instrumen zakat, infak dan sedekah. Hal ini termaktub dalam firman Allah swt: "(yaitu) orang-orang yang menafkahkan (hartanya), baik di waktu lapang maupun sempit, dan orangorang yang menahan amarahnya dan mema'afkan (kesalahan) orang. Allah menyukai orang-orang yang berbuat kebajikan.”(Q.s. Ali Imran [3]: 134).

Dalam sistem ekonomi Islam, harta merupakan modal atau faktor produksi penting, tapi bukan yang terpenting. Yang terpenting adalah manusia itu sendiri, dan menempatkan alam sebagai modal dan faktor produksi kedua. Memang betul adanya, modal tidak boleh diabaikan, namun wajib menggunakannya dengan baik agar produktifitas dan kemanfaatan harta terus ada.

Dalam sistem ekonomi Islam, harta memiliki fungsi yang terus dimanfaatkan oleh manusia, sehingga kecenderungan manusia untuk terus menguasai dan memiliki harta tidak pernah surut. Dalam hal ini syariat memberikan batasan fungsi dan peran harta, diantaranya adalah; Pertama, untuk mendukung kegiatan peribadatan, seperti menggunakan kain sarung untuk menunjang ibadah sholat. Kedua, untuk memelihara dan meningkatkan keimanan sebagai usaha mendekatkan diri kepada Allah swt, seperti bersedekah dengan harta. Ketiga, untuk keberlangsungan hidup dan estafet kehidupan. Keempat, untuk menyelaraskan kehidupan di dunia dan akhirat. ${ }^{17}$

${ }^{16}$ Muhammad al-Assal, Sistem Prinsip dan Tujuan Ekonomi Islam, diterjemahkan oleh Drs. H. Imam Saefudin, (Bandung: Pustaka Setia, 1999), h. 44.

${ }^{17}$ Hendi Suhendi, Fiqih Muamalah, (Bandung: Gunung Djati Press, 1997), h. 28-30. 
Dalam sistem ekonomi Islam, cara memperoleh harta juga diatur sedemikian rupa, sehingga ada beberapa etika dan hukum yang patut diperhatikan disaat mencari nafkah ataupun bekerja. ${ }^{18}$ Dalam hal ini Allah Swt berfirman, "Dialah Yang menjadikan bumi itu mudah bagi kamu, maka berjalanlah di segala penjurunya dan makanlah sebahagian dari rezki-Nya. Dan hanya kepada-Nya-lah kamu (kembali setelah) dibangkitkan.” (QS. al-Mulk [67]: 15), "Hai orang-orang beriman, janganlah hartamu dan anak-anakmu melalaikan kamu dari mengingat Allah. Barangsiapa yang berbuat demikian maka mereka itulah orang-orang yang merugi." (QS. al-Munafikun [63]: 9), dan "Dan janganlah sebahagian kamu memakan harta sebahagian yang lain di antara kamu dengan jalan yang bathil dan (janganlah) kamu membawa (urusan) harta itu kepada hakim, supaya kamu dapat memakan sebahagian daripada harta benda orang lain itu dengan (jalan berbuat) dosa, padahal kamu mengetahui." (QS. al-Baqoroh [2]: 188).

Dalam sistem ekonomi Islam juga diatur bagaimana cara mendapatkan harta yang sesuai dengan syariat agama Islam, dalam hal ini ada beberapa cara untuk mendapatkan harta, diantaranya adalah; Pertama, bercocok tanam dan menghidupkan tanah mati, Rasulullah saw bersabda "Tak seorang muslim pun yang menanam tanaman, lalu dimakan oleh seekor burung atau manusia dan hewan, kecuali baginya merupakan bentuk sedekah" (HR. Bukhori dan Muslim). ${ }^{19}$ Dari hadis ini jelas bahwa orang yang bercocok tanam akan bersedekah terus-menerus sebab tidak mungkin ada satu tanaman pun yang tidak termakan oleh burung, manusia ataupun hewan lainnya. Usaha dengan cara bercocok tanam mengandung semacam penyerahan diri kepada Allah swt, karena setelah mengelola tanah dan menebar bibit dan mengairinya, penyerahan diri itu ada pada saat menunggu tanaman itu tumbuh dan berbuah. $^{20}$ Adapun hadis yang menerangkan tentang menghidupkan tanah mati, bahwasannya Rasulullah saw pernah bersabda "Barang siapa yang menghidupkan tanah mati, maka tanah itu miliknya". ${ }^{21}$ Para ulama fiqih sepakat bahwa menghidupkan tanah mati merupakan sebab untuk memilikinya. Bahkan dari mereka menyatakan untuk memilikinya tidak diperlukan izin dari pemerintah. Kedua, dengan cara bekerja, Rasulullah saw bersabda "Tidak seorang pun memakan satu makanan yang lebih baik kecuali dari hasil kerjanya sendiri karena sesungguhnya Nabi Daud as makan dari hasil kerjanya sendiri" (HR. Bukhori). ${ }^{22}$ Ketiga, Akad perpindahan hak milik, seperti jual-beli. ${ }^{23}$ Dalam hal ini Rasulullah saw pernah bersabda, "Kedua belah pihak

${ }^{18}$ Lihat, Fathurrahman Djamil, Hukum Ekonomi Islam, (Jakarta: Sinar Grafika, 2013), h. 183-184. Ika Yunia Fauzia, Etika Bisnis dalam Islam, (Jakarta: Kencana, 2013), h. 2931. Faisal Badroen, Etika Bisnis dalam Islam, (Jakarta: Kencana, 2006), h. 36-38.

${ }^{19}$ Sunan al-Baihaqi, Bab Fadlu al-Zari wa al-Gorsi Iza Akala, jilid 2, h. 87.

20 Lihat, Muhammad al-Assal, Sistem Prinsip dan Tujuan Ekonomi Islam, diterjemahkan oleh Imam Saefudin, (Bandung: Pustaka Setia, 1999), h. 55.

${ }^{21}$ Shohih al-Bukhori, Bab Man Ahya Ardhon Mawatan, jilid 2, h. 822.

${ }^{22}$ Shohih al-Bukhori, Bab Kasbu al-Rojuli wa Amalihi Biyadihi, jilid 2, h. 730.

${ }^{23}$ Suharwardi K. Lubis, et. al, Hukum Ekonomi Islam, (Jakarta: Sinar Grafika, 2012),

h. 139. 
memiliki hak untuk memilih selama keduanya belum berpisah, maka jika keduanya jujur diberkahilah mereka keduanya di dalam transaksi jual beli itu, akan tetapi jika keduanya berdusta dan curang saling menyembunyikan maka keberkahan itu akan hilang dari transaksi jual-beli itu" (HR. Muslim). ${ }^{24}$ Keempat, dengan cara waris dan lainnya. Dan kelima dengan cara penantian, seperti kedudukan istri dan anak yang menantikan hak nafkah dari seorang kepala rumah tangga. ${ }^{25}$

\section{Konsep Memelihara Harta Menurut Maqoshid al-Syariah}

Maqoshid syariah terdiri dari dua kata yakni مقاصد dan الثريعة. Maqoshid adalah jamak yang berarti mendatangkan sesuatu, tuntutan, kesengajaan dan tujuan. ${ }^{26}$ Syariah menurut bahasa berarti jalan menuju sumber air, yang dapat pula diartikan sebagai jalan ke arah sumber pokok keadilan. ${ }^{27}$

Wahbah al-Zuhaili berpendapat bahwa maqoshid syariah adalah nilainilai dan sasaran hukum yang tersirat dalam segenap atau bagian terbesar dari hukum-hukumnya. Nilai-nilai dan sasaran-sasaran itu dipandang sebagai tujuan dan rahasia syariah, yang ditetapkan oleh pembuat hukum (al-syaari) dalam setiap ketentuan hukum. ${ }^{28}$

Yusuf Al-Qardhawi mendefinisikan bahwa maqoshid syariah adalah sebagai tujuan yang menjadi target teks dan hukum-hukum partikular untuk direalisasikan dalam kehidupan manusia, baik berupa perintah, larangan dan mubah; yang diperuntukan kepada individu, keluarga, kelompok dan umat, atau juga disebut dengan hikmat-hikmat yang menjadi tujuan ditetapkannya hukum, baik yang diharuskan ataupun tidak. Karena dalam setiap hukum yang disyariatkan Allah kepada hambaNya pasti terdapat hikmah, yaitu tujuan luhur yang ada di balik hukum. ${ }^{29}$

Menurut salah satu ulama ushul fiqh, Imam Syathibi, maqoshid syariah adalah tujuan Allah dan Rasul-Nya dalam merumuskan hukum-hukum Islam. Tujuan itu dapat ditelusuri dalam ayat-ayat Al-Qur'an dan Sunnah Rasulullah sebagai alasan logis bagi rumusan suatu hukum yang berorientasi kepada kemaslahatan umat manusia. Sebagaimana dikemukakan dalam bukunya yang monumental, al-Muwafaqot, Imam Syathibi menyatakan bahwa tujuan pokok disyariatkan hukum Islam adalah untuk kemaslahatan manusia baik di dunia

${ }^{24}$ Shohih Muslim, Bab al-Sidu fi al-Bai, jilid 5, h. 10.

Lihat, Muhammad al-Assal, Sistem Prinsip dan Tujuan Ekonomi Islam, diterjemahkan oleh Imam Saefudin, (Bandung: Pustaka Setia, 1999), h. 56.

${ }^{26}$ Ahsan Lihasanah, Al-Fiqh al-Maqoshid Inda al-Imam al-Syathibi, (Dar al-Salam: Mesir, 2008), h. 11.

${ }^{27}$ Yusuf Al-Qardhawi, Fiqih Maqoshid Syariah, (Pustaka al-Kautsar: Jakarta, 2007), h.

225.

${ }^{28}$ Wahbah al-Zuhaili, Ushul Fiqh Islami, (Dar al-Fikri: Damaskus, 1986), Juz II, h. $13-19$

\footnotetext{
${ }^{29}$ Yusuf Al-Qardhawi, Fiqih Maqoshid Syariah, (Pustaka al-Kautsar: Jakarta, 2007), h.
} 
maupun di akhirat. Kemaslahatan yang akan diwujudkan itu adalah dharuriyat, hajiyat, dan tahsiniyat. ${ }^{30}$

Adapun formula yang ditawarkan Islam di dalam memelihara atau menjaga harta yang sesuai dengan maqoshid syariah adalah memperioritaskan perihal yang primer dan menjaga keutuhan yang primer tersebut dengan perihal-perihal pendukung lainnya. Seperti yang telah dijelaskan diatas bahwa, maqoshid syariah terdiri dari menjaga agama (حفظ الدين), menjaga jiwa (حفظ), حفظ (الفظ), (النفس), menjaga akal (حفظ العقل), menjaga keturunan (حفظ النسل), dan menjaga harta (حفظ المال). Formula maqoshid syariah di dalam memelihara atau menjaga harta adalah tetap memprioritaskan perihal yang primer yaitu menjaga agama dan dengan menjaga keutuhan yang primer dengan perihal lainnya, termasuk diantaranya adalah menjaga harta (حفظ المال). Para ulama ushul sepakat bahwa perihal yang primer yaitu menjaga agama (حفظ الدين) tidak bisa digantikan kedudukannya, dan perihal menjaga harta (حفظ المال) tidak bisa menempati perihal yang primer menggeser posisi menjaga agama (حفظ الدين). Dan juga, bahwa perihal menjaga harta (حفظ المال) adalah penting adanya untuk menjaga keutuhan agama (حفظ الدين), hingga dikatakan bahwa harta yang rusak dapat mempengaruhi kemurnian agama. Namun demikian, para ulama ushul tidak berselisih paham terhadap perbedaan kedudukan dan posisi dari menjaga jiwa (حفظ النفس), menjaga akal (حفظ العقل), menjaga keturunan (حفظ النسل), dan menjaga harta (حفظ المال). ${ }^{31}$

Sebagai contoh di dalam kegiatan muamalah adalah, bahwa sholat jum'at (حفظ الدين) merupakan perihal yang primer dan utama untuk dikerjakan daripada kegiatan muamalah jual-beli (حفظ المال), dalam hal ini Allah swt berfirman "Hai orang-orang beriman, apabila diseru untuk menunaikan shalat Jum'at, maka bersegeralah kamu kepada mengingat Allah dan tinggalkanlah jual beli. Yang demikian itu lebih baik bagimu jika kamu mengetahui”. (QS. alJumuah [62]: 9). Contoh yang lainnya adalah, bahwa materi harta yang rusak dapat mempengaruhi keutuhan perihal yang primer; seperti sholat yang menggunakan sarung curian.

Imam Syathibi menguraikan tentang bagaimana menjaga/memelihara harta sesuai dengan ketentuan maqoshid syariah, yaitu adanya ketetapan hukum yang dilegalkan oleh Allah swt tentang diharamkannya mencuri dan sangsi atasnya, diharamkannya curang dan berkhianat di dalam bisnis, diharamkannya riba, diharamkannya memakan harta orang lain dengan cara yang bathil, dan diwajibkan untuk mengganti barang yang telah dirusaknya; sehingga dengan demikian terjagalah/terpeliharalah harta. ${ }^{32}$

30 Lihat, Al-Syathibi, al-Muwafaqot fi Ushul al-Syariah, (Kairo: Musthofa Muhammad), jilid 2, h. 324.

${ }_{31}$ Lihat, Al-Syathibi, al-Muwafaqot fi Ushul al-Syariah, (Kairo: Musthofa Muhammad), jilid 2, h. 326.

32 Lihat, Al-Syathibi, al-Muwafaqot fi Ushul al-Syariah, (Kairo: Musthofa Muhammad), jilid 2, h. 6-7. 
Wahbah al-Zuhaili juga menguraikan bagaimana peranan maqoshid syariah di dalam menjaga/memelihara sesuatu yang primer dari harta tersebut, yaitu dengan dilarangnya pemborosan harta dari hal-hal yang dibutuhkan, dilarangnya penumpukan harta di tangan orang-orang kaya, dan diwajibkannya infak dan sedekah untuk pemerataan harta dalam rangka memberikan kemaslahatan bagi manusia keseluruhan. ${ }^{33}$

\section{Konsep Maslahat Memelihara Harta Dalam Sistem Ekonomi Islam}

Berbeda dengan agama lainnya, Islam adalah satu-satunya agama yang memiliki sistem ekonomi, yaitu sistem dan aturan berupa etika dan hukum yang 'langsung' dibuat oleh Allah swt sendiri dan menjadikan Rasulullah saw sebagai contoh aplikatif dari sistem ekonomi tersebut. ${ }^{34}$ Sistem ekonomi Islam tidak berdiri sendiri dan terlepas dari syariah. ${ }^{35}$ Sistem ekonomi Islam adalah bagian dari syariah, sehingga dalam uraian di atas ada pembahasan tentang maqoshid syariah yang menjelaskan tentang harta, memelihara/ menjaga harta serta penjelasan bagaimana sistem ekonomi yang diketengahkannya.

Adapun konsep maslahat memelihara harta dalam sistem ekonomi Islam, Dr. Ali Musa Husain dalam risalah disertasinya yang berjudul Maqshodu Hifdzu al-Mal fi al-Tashorufat al-Maliyah mengungkapkan, bahwa ada tiga pokok penting yang perlu diperhatikan di dalam menjaga/memelihara harta dalam kegiatan muamalah, yaitu, dengan pencatatan, dengan persaksian, dan dengan penyertaan dokumentasi. ${ }^{36}$ Hal ini sesuai dengan maksud yang terkandung di dalam firman Allah swt: "Hai orang-orang yang beriman, apabila kamu bermu'amalah tidak secara tunai untuk waktu yang ditentukan, hendaklah kamu menuliskannya. Dan hendaklah seorang penulis di antara kamu menuliskannya dengan benar. Dan janganlah penulis enggan menuliskannya sebagaimana Allah mengajarkannya, maka hendaklah ia menulis, dan hendaklah orang yang berhutang itu mengimlakkan (apa yang akan ditulis itu), dan hendaklah ia bertakwa kepada Allah Tuhannya, dan janganlah ia mengurangi sedikitpun daripada hutangnya. Jika yang berhutang

${ }^{33}$ Wahbah al-Zuhaili, Maqhosid al-Syariah al-Islamiyah fi al-Mal wa al-Iqtishad alIslami, makalah disampaikan dalam seminar The Second Islamic Economics and Finance Research Forum oleh Ikatan Ahli Ekonomi Islam di UIN Syarif Hidayatullah Jakarta 13-14 November 2013. h. 5.

${ }^{34} \mathrm{Hal}$ ini banyak sekali ayat al-Qur'an ataupun hadis nabi yang mengurai konsep dasar bermuamalah ataupun kegiatan ekonomi, diantaranya adalah: konsep dasar harta, bekerja, jualbeli, hutang, gadai, produksi, konsumsi, distribusi, investasi, akuntansi, manajemen harta, instrumen jaminan sosial, waris, wakaf, zakat, infak, sedekah, pajak, dan konsep dasar lainnya yang berkenaan dengan kegiatan ekonomi. Hanya agama Islam yang memiliki konsep dasar ekonomi dan tidak ada agama selain Islam yang memiliki konsep ekonomi ataupun sistem ekonomi tersebut.

${ }^{35}$ Lihat, Wahbah al-Zuhaili, Maqhosid al-Syariah al-Islamiyah fi al-Mal wa al-Iqtishad al-Islami, makalah disampaikan dalam seminar The Second Islamic Economics and Finance Research Forum oleh Ikatan Ahli Ekonomi Islam di UIN Syarif Hidayatullah Jakarta 13-14 November 2013. h. 5-6.

${ }^{36}$ Lihat, Ali Musa Husain, Maqshodu Hifdzu al-Mal fi al-Tashorufat al-Maliyah, Disertasi, h. 147-150. 
itu orang yang lemah akalnya atau lemah (keadaannya) atau dia sendiri tidak mampu mengimlakkan, maka hendaklah walinya mengimlakkan dengan jujur. Dan persaksikanlah dengan dua orang saksi dari orang-orang lelaki (di antaramu). Jika tak ada dua oang lelaki, maka (boleh) seorang lelaki dan dua orang perempuan dari saksi-saksi yang kamu ridhai, supaya jika seorang lupa maka yang seorang mengingatkannya. Janganlah saksi-saksi itu enggan (memberi keterangan) apabila mereka dipanggil; dan janganlah kamu jemu menulis hutang itu, baik kecil maupun besar sampai batas waktu membayarnya. Yang demikian itu, lebih adil di sisi Allah dan lebih menguatkan persaksian dan lebih dekat kepada tidak (menimbulkan) keraguanmu. (Tulislah mu'amalahmu itu), kecuali jika mu'amalah itu perdagangan tunai yang kamu jalankan di antara kamu, maka tidak ada dosa bagi kamu, (jika) kamu tidak menulisnya. Dan persaksikanlah apabila kamu berjual beli; dan janganlah penulis dan saksi saling sulit menyulitkan. Jika kamu lakukan (yang demikian), maka sesungguhnya hal itu adalah suatu kefasikan pada dirimu. Dan bertakwalah kepada Allah; Allah mengajarmu; dan Allah Maha Mengetahui segala sesuatu”. (Q.s. al-Baqoroh [2]: 282).

Dengan pencatatan, konsep maslahat memelihara harta dalam sistem ekonomi Islam yang dimaksud adalah, menghilangkan keraguan diantara pihak yang bertransaksi, memberi penjelasan yang nyata jika terjadi sengketa, menjaga harta atau objek transaksi dari hal-hal yang menguranginya ataupun menghilangkannya, menghindari kelalaian dan penipuan, dan mengikat para pihak yang bertransaksi untuk hak dan kewajibannya. ${ }^{37}$ Dengan persaksian, konsep maslahat memelihara harta dalam sistem ekonomi Islam yang dimaksud adalah, menjaga kegiatan transaksi dari kecurangan, menghilangkan keraguan dari berkurangnya hak atas kegiatan transaksi, dan berfungsi menguatkan informasi diantara pihak yang bertransaksi. ${ }^{38}$ Dan dengan penyertaan dokumentasi, konsep maslahat memelihara harta dalam sistem ekonomi Islam yang dimaksud adalah, menjadikannya sebagai penguat atau bukti hukum, memelihara perkara transaksi yang telah berlalu lama, dan menjadi pedoman pihak yang bertransaksi dari kefasikan dan kecurangan. ${ }^{39}$

Selain dari hal di atas, di dalam fiqih muamalah, memelihara harta juga dikemukakan dengan berbagai macam, diantaranya adalah dengan cara jualbeli, investasi, sewa-menyewa, dan lain sebagainya. ${ }^{40}$ Kemaslahatan memelihara harta dalam Islam benar-benar diperhatikan, hal ini diperuntukan bagi manusia agar satu dengan yang lainnya tidak memakan harta dengan cara yang bathil, agar hak dan kewajiban atas harta dari masing-masing yang bertransaksi terjaga dan terselamatkan dari kefasikan, dan agar ketentraman bagi pihak yang

${ }^{37}$ Lihat, Ali Musa Husain, Maqshodu Hifdzu al-Mal fi al-Tashorufat al-Maliyah, Disertasi, h. 152.

${ }_{38}$ Lihat, Ali Musa Husain, Maqshodu Hifdzu al-Mal fi al-Tashorufat al-Maliyah, Disertasi, h. 165.

${ }_{39}$ Lihat, Ali Musa Husain, Maqshodu Hifdzu al-Mal fi al-Tashorufat al-Maliyah, Disertasi, h. 170.

${ }^{40}$ Lihat, Helmi Karim, Fiqh Muamalah, (Jakarta: Raja Grafindo Persada, 1997), h. 83100. 
bertransaksi terwujudkan. Inilah konsepsi dan sekaligus teori aplikatif yang diberikan oleh Allah swt terhadap hambaNya di dalam memelihara/menjaga harta.

\section{Penutup}

Sesungguhnya, Allah swt sebagai pemilik sejati akan harta telah memberikan pedoman yang terkandung di dalamnya kemaslahatan yang diperuntukan bagi manusia sekalian. Kemaslahatan ini adalah maqoshid alsyaari (tujuan/maksud Allah swt) yang pada hakikatnya harus dipahami dan dimengerti oleh manusia di dalam memelihara/menjaga harta. Bahwa dengan memelihara/menjaga harta, manusia akan terselamatkan hidupnya di dunia ataupun di akhirat, hak dan kewajiban manusia akan harta terjaga dengan semestinya, dan tidak ada kefasikan yang dikhawatirkan bagi pihak-pihak yang bertransaksi.

\section{Pustaka Acuan}

Abidin, Ibnu, Hasyiatu Rodu al-Mukhtar.

Assal, al-, Muhammad, Ahmad, et, al. Sistem, Prinsip dan Tujuan Ekonomi Islam, diterjemahkan oleh Imam Saefudin, Bandung: Pustaka Setia, 1999.

Badroen, Faisal, Etika Bisnis dalam Islam, Jakarta: Kencana, 2006.

Djamil, Fathurrahman, Dr. Prof., Hukum Ekonomi Islam, Jakarta: Sinar Grafika, 2013.

Fauzia, Yunia, Ika, Etika Bisnis dalam Islam, Jakarta: Kencana, 2013.

Ghazali, al-, al-Mustashfa min Ilmi al-Ushul, Beirut: Darul Ulum al-Haditsah.

Husain, Musa, Dr. Ali, Maqshodu Hifdzu al-Mal fi al-Tashorufat al-Maliyah, Disertasi.

Islahi, A., Konsepsi Ekonomi Ibnu Taimiyah, diterjemahkan oleh Anshari Thayib, Surabaya: PT. Bina Ilmu, 1997.

Karim, Helmi, Fiqh Muamalah, Jakarta: Raja Grafindo Persada, 1997.

Lihasanah, Ahsan, Al-Fiqh al-Maqoshid Inda al-Imam al-Syathibi, Dar alSalam: Mesir, 2008.

Lubis, K., Suhrawardi, et. al, Hukum Ekonomi Islam, Jakarta: Sinar Grafika, 2012.

Mabid, al-, Ahmad, Muhammad, Dr., Maslahah Hifdzu al-Nafsi fi al-Syariah al-Islamiyah, Mesir: Muasasah al-Mukhtar, 2004.

Qardhawi, al-, Yusuf, Fiqih Maqoshid Syariah, Pustaka al-Kautsar: Jakarta, 2007.

Qordhowi, al-, Yusuf, Fi Fiqh al-Awlawiyat, Beirut: al-Maktab al-Islami, 1999.

Rogibah, Bin, Izudin, al-Maqoshid al-Syariyah al-Hosoh bi al-Tasyarufat alMaliyah.

Salam, Abdi, Ibnu, Qowaid al-Ahkam fi Masholihu al-Anam, Beirut: Darul Jail.

Shohih al-Bukhori, Bab Kasbu al-Rojuli wa Amalihi Biyadihi.

Shohih al-Bukhori, Bab Man Ahya Ardhon Mawatan.

Shohih Muslim, Bab al-Sidu fi al-Bai. 
Suhendi, Hendi, Fiqih Muamalah, Bandung: Gunung Djati Press, 1997.

Sunan al-Baihaqi, Bab Fadlu al-Zari wa al-Gorsi Iza Akal.

Syafei, Rachmat, Dr. Prof., Fiqih Muamalah, Bandung: Pustaka Setia, 2006.

Syathibi, al-, al-Muwafaqot fi Ushul al-Syariah, Kairo: Musthofa Muhammad.

Syaukani, al-, Irsyadul fuhul ila Tahqiqi al-Haq min Ilmi al-Ushul, Mesir: Matba'ah al-Babi al-Halabi.

Thufi, al-, al-Maslahah fi al-Tasyri al-Islami.

Zaid, Musthofa, Dr., al-Maslahah fi al-Tasyri al-Islami, Mesir: Matba'ah alJaizah.

Zuhaili, al-, Wahbah, al-Fiqh al-Islami wa Adilatuhu, Damaskus: Darul Fikri, 1989.

Zuhaili, al-, Wahbah, Maqhosid al-Syariah al-Islamiyah fi al-Mal wa al-Iqtishad al-Islami, makalah disampaikan dalam seminar The Second Islamic Economics and Finance Research Forum oleh Ikatan Ahli Ekonomi Islam di UIN Syarif Hidayatullah Jakarta 13-14 November 2013.

Zuhaili, al-, Wahbah, Nadhoriyat al-Dhoruroh al-Syariyah, Beirut: Darul Fikri al-Muasir, 1997.

Zuhaili, al-, Wahbah, Ushul Fiqh Islami, Dar al-Fikri: Damaskus, 1986. 